\title{
Board diligence, independence, size, and firm performance: Evidence from Saudi Arabia
}

\author{
Sultan Altass ${ }^{\mathbf{a}^{*}}$
}

${ }^{a}$ College of Business, King Abdulaziz University, Saudi Arabia

\section{A B S T R A C T}

\begin{abstract}
The aim of this paper is to examine the possible association between the effectiveness of Board of Directors (BOD) and firm performance (FP). For the purpose of this analysis, data is derived from firms listed in the materials sector of the Saudi Exchange Market's Tadawul All Share Index (TASI). Using pooled OLS regression analysis and the dependent variables of ROA and ROE as a proxy for FP, while board meetings (BMEET), independence and board size (BSIZE) are used as explanatory variables, the results reveal that frequent BMEET may not lead to improved FP. Moreover, the results show that BMEET frequency is negatively associated with FP. Independent members do not provide additional efficiency leading to better FP. As for the BSIZE, the findings indicate that larger boards are associated with lower FP. Such findings offer insights into the effect of BSIZE on FP. The results are of interest to decision makers, policymakers and investors.
\end{abstract}

C 2022 Growing Science Ltd. All rights reserved.

\section{Introduction}

Firm corporate governance (CG) is an essential control and management tool which safeguards the owners' interests and helps establish robust financial oversight and improved performance. The importance of a robust form of CG stems from the need for well-established internal control and financial integrity on the part of a firm. The collapse in the first decade of the century of high-profile corporations such as the US energy giant Enron, WorldCom (MCI Inc.) the second largest telecommunication in the United States at that time, and the fourth largest investment bank in the US, Lehman Brothers are prime examples of the main cause of the growing scrutiny worldwide regarding firms' management and their role in harming public interest (Zamansky, 2011; Sunderland, 2010; Sikka, 2008a, 2008b, 2009; Weir et al., 2002). This was, in part, due to the apparent malpractices of corporate directors, particularly in the form of misrepresenting corporate financial reality. Such practices are chiefly motivated by market incentives to meet unrealistic financial key performance Indicators (KPIs) and shareholder expectations, hence enhancing the firm's performance image in terms of profitability and growth prospects (Graham et al., 2005). The prominent agency theory proposed by Jensen and Meckling (1976) offers insights vis-à-vis management (agents) behavior whereby they are hired to lead daily activities and operations of the firm in order, apparently, to contribute to the interests of the firm owners (the principals). However, in fact, management may engage in opportunistic practices and exercise their power in order to achieve personal objectives. These practices are driven by economic pressures to meet market expectations, hence enhancing the firm's performance indicators, including profitability and earnings (Graham et al., 2005). This issue may in turn offer an additional understanding of the crucial role of CG in mitigating the agency problem. As asserted by Kakanda et al. (2016), the survival of a firm as well as its growth and going concern status, is subject to corporate performance. According to Zabri et al. (2016), the BOD represents the overarching governance tool in today's capital markets. This paper identifies three board attributes that have been extensively examined in the literature. These are BMEET, board members' independence, and BSIZE. The importance of examining these attributes in association with FP is grounded in the view that CG mechanisms such as BOD, play a crucial role in safeguarding the interests of

* Corresponding author

E-mail address: saltass@kau.edu.sa (S. Altass)

(C) 2022 Growing Science Ltd. All rights reserved. doi: $10.5267 /$ j.ac.2022.1.001 
shareholders, and hence, enhancing a firm's financial performance (Eluyela et al., 2018). Previous research in the area of board characteristics (BC) and FP offers insights into the relationship between board attributes and FP. However, the literature provides inconclusive results regarding such an association. Therefore, the aim of this paper is to examine the possible association between firm performance and the characteristics of BOD, namely, BMEET, the independence of board members, and BSIZE utilizing data derived from firms listed in the materials sector of the Saudi Exchange Market's Tadawul All Share Index (TASI).

The paper is structured as follows: Section 2 provides a thorough literature review, while Section 3 highlights the methodology used in this research. Section 4 offers the empirical results of the study. Finally, Section 5 offers concluding remarks.

\section{Literature review}

Previous research with regard to CG offers important insights into the crucial role of robust CG when it comes to enhancing the likelihood of achieving a firm's objectives, particularly with regard to financial performance. This paper aims to investigate the possible association between CG quality and FP in terms of the Saudi public limited firms' landscape. These attributes are frequency of board meetings (BMEET), BOD members' independence, and BSIZE.

\subsection{Board Meetings}

It has been recently shown that CG is a fundamental tool to enable a firm to excel financially in today's complex and highly competitive markets. This is, in part, due to the increasingly closely-scrutinized management (Agent) behavior, resulting from their pursuit of opportunistic financial goals, and not ensuring shareholders' (Principal) interests following the separation of ownership and control (Fama \& Jensen, 1983). Therefore, the BOD of a company is perceived as a central mechanism for managing that company's operations and the strategic business decision making process. On the other hand, one of the key features utilized recently as a proxy for the quality of the BOD is board diligence, or BMEET throughout a year (Ghosh, 2007; Katmon et al., 2018; Johl et al., 2015; Ilaboya and Obaretin, 2015). In the Saudi context, according to Saudi Companies Law, the BOD of public limited companies must meet at least twice a year (Ministry of Commerce, 2016). Members who did not attend three consecutive board meetings shall be removed from the board. However, the maximum number of meetings in a year has not been specified in law. In their study of 700 Malaysian firms for the year 2009, Johl et al. (2015) examined the relationship between BMEET and FP. The analysis reveals that a high meeting frequency has an adverse effect on FP. In contrast, the study by Eluyela et al. (2018) suggests the opposite. Their study examined a sample of 15 Nigerian financial institutions for the period 2011-2016 and found that BMEET has a positive impact on FP. Therefore, their results offer a different perspective on the board frequency-performance relationship. Another study conducted in Malaysia by Taghizadeh and Saremi (2013) involving 150 firms for the year 2008, revealed that the increased frequency of BOD meetings is associated with lower FP. This finding provides support to the other Malaysian study by Johl et al. (2015). Based on the literature review on the relationship between BOD meetings and FP, there are two conflicting views in the literature regarding the effect of the high and low frequency of BMEET. However, it is expected that frequent BMEET in a given year is associated with improved and this leads us to the following hypothesis:

$\mathbf{H}_{1}$ : There is a significant relationship, ceteris paribus, between board meetings and firm performance.

\subsection{Board Independence}

The Capital Market Authority (CMA) of Saudi Arabia recognizes the importance of the proportion of non-executive board members and their independence. They have published guidelines which state that the number of such members must not be less than three, or a third of the overall composition of the board (CMA, n.d.). Non-executive board members represent two focal characteristics - being independent from the firm ownership and, most importantly, being responsible for keeping their professional status in the market (Fama \& Jensen, 1983). Recent research into board independence (IND) and FP is growing, but it is characterized as being mixed in terms of the findings. The seminal work by Pfeffer and Salancik (2003) endorses the resource dependence theory which argues that modern firms may attract external resources that enable them to gain access to higher quality expertise and skills and empower firm performance to attract additional resources. Many recent studies have embraced resource dependence theory to understand IND and the FP phenomenon. For example, AlMatari et al. (2014) conducted a study of Omani firms over a two-year period (2011-2012) and found that the relationship between IND and FP is non-significant. However, in a study that examined the relationship between IND and FP in Ghana, Sarpong-Danquah et al. (2018) documented a strong positive relationship between IND and FP. Nevertheless, following the review of the literature on the association between independence of the BOD and FP, it was revealed that there is no agreement on the direction and significance of such a relationship, especially in research conducted in developing countries where CG has not been strongly mandated in most markets. Another recent study conducted in Taiwan for the period $1997-$ 2015 investigated this phenomenon (Kao et al., 2018). The authors investigated the relationship between BC and FP. In particular, the study examined the association between independent directors and FP. In fact, the results found that greater IND is associated with improved FP. As shown in the previous literature which attempted to investigate this relationship, 
we can see that there is consensus that a higher proportion of IND is associated with strong FP, lending support to resource dependence theory (Pfeffer \& Salancik, 2003). Therefore, the second hypothesis will be formulated as follows:

$\mathrm{H}_{2}$ : There is a significant relationship, ceteris paribus, between Board independence and firm performance.

\subsection{Board Size}

Research into BOD size and FP is growing, albeit arriving at inconclusive findings. Some observers believe that a larger BSIZE is likely to trigger agency costs and may result in an inverse effect due to the free rider effect and the likelihood that larger boards hinder both effectiveness and the decision-making process (Kao et al., 2018; Jensen, 1993; Lipton and Lorsch, 1992; Dwivedi and Jain, 2005). On the other hand, another body of literature is in favor of large BSIZE, arguing that larger boards offer more robust monitoring, and provide opportunities for better FP (Ramdani \& van Witteloostuijn, 2010; Adams \& Ferreira, 2007; Mangena et al., 2012; Choi et al., 2007; Kiel \& Nicholson, 2003; Lefort \& Urzu a, 2008). Previous researchers have attempted to recognize the optimal BSIZE so that a firm could then operate effectively. For example, Jensen (1993) proposed an optimum BSIZE of between seven and eight. Nevertheless, there is no obvious consensus on the optimal BSIZE within the board-performance literature. Using a sample of 450 companies collected from ten North American and European countries in 1996, De Andres et al. (2005) reported a negative association between BSIZE and FP. Moreover, Cheng (2008) examined the relationship between BSIZE and FP variability based on 1,252 US firms for the period 1996-2004. Their analysis found that there is a negative relationship between BSIZE and FP. Similarly, another study conducted in the Taiwanese market by Young et al. (2008) utilized a sample of 492 companies for the period 2001-2002. They documented a negative relationship between BSIZE and FP. In Greece, Drakos and Bekiris (2010) examined the relationship between BSIZE and FP using a sample of 1,409 companies for the period 2000-2006. Their analysis revealed a negative relationship between BSIZE and FP. Nevertheless, looking at the previous literature, we can note that other studies did not find a significant association between IND and FP (Prevost et al., 2002; Lefort \& Urzu a, 2008; Ramdani \& van Witteloostuijn, 2010 Dahya et al., 2016). On the other hand, another body of research in this area found an adverse effect in terms of IND on FP (Bhagat \& Black, 2001; Kiel \& Nicholson, 2003; Mangena et al., 2012; Cavaco et al., 2017; Zhou et al., 2018). However, as shown in the literature detailed above, the majority of studies, whether conducted in developed or developing markets, found that the relationship between BSIZE and FP appears to be significantly negative, meaning, as Kao et al. (2018) posit, larger BSIZE may increase agency cost and lower the monitoring power of the board. Therefore, the third hypothesis will be formulated as follows:

\section{H3: There is a significant relationship, ceteris paribus, between board size and firm performance.}

\section{Methodology}

This study aims to examine the possible association between the characteristics of a BOD, namely, the independence of board members, BSIZE and BMEET in any one year. To achieve this objective, the sample of this study consists of a population which includes the materials firms listed on the Saudi Exchange Market's Tadawul All Share Index (TASI). The total number of firms is 42 . The reason for selecting this industry is that it represents one of the most important sectors within TASI in terms of market capitalization, growth prospects, and investment opportunities. The time covered in this study is from 2014 to 2018 . Therefore, the aggregate observations arrive at 210 firm-years. Data for all the variables were collected from the annual reports of the sampled firms. The variables which have been collected from published annual reports are summarized in Table 1.

Table 1

Summary of variables

\begin{tabular}{|c|c|c|}
\hline Variables & Definition & Predicted Sign \\
\hline (PERF) ROE & Natural logarithm of the net income divided by shareholder equity & D. Var \\
\hline (PERF) ROA & Natural logarithm of the net income divided by total assets & D. Var \\
\hline IND & The ratio of independent members in the BOD & + \\
\hline BMEET & Number of BOD meetings per year & + \\
\hline BSIZE & BOD size & - \\
\hline SIZELG & Natural log of firm total assets at year end & + \\
\hline LEV & Ratio of firm long-term debt-to-total assets at year end & + \\
\hline
\end{tabular}

To analyze the collected data, this study utilizes the Pooled Ordinary Least Square regression model (Pooled OLS). The model used to analyze the data that examine the relationship between IND and FP is presented in the following equation:

$P E R F=\beta_{0}+\beta_{1} I N D(B M E E T /$ BSIZE $)+$ Control Variables $+e$

This study attempts to investigate this phenomenon using two dependent variables (both used for each model) in a way that provides a robust analysis. This differs from most of the previous pieces of research which were based in developing countries and which use only one dependent variable. Therefore, in this study, ROE and ROA are both used in the three models to examine the association between BOD characteristics and FP. As for the independent variables, this study employs three BCs which have not previously been analyzed extensively together in developing markets. These are the ratio of independent members in the BOD, the number of board meetings and BSIZE. The control variables, SIZELG and LEV, 
were selected based on several previous pieces of research in the field of CG and FP (e.g., Bhatt \& Bhattacharya, 2017; Aljifri \& Moustafa, 2007; Haniffa \& Hudaib, 2006).

\section{Empirical results}

Table 2 below presents a summary statistic of all the variables used in this study, where ROA and ROE represents the dependent variable and denotes a FP proxy. Similarly, IND, BMEET and BSIZE represent the independent variables which act as BOD characteristics. As can be seen in Table 2, the ROA has a mean of 0.054 , with the variable being calculated as the natural logarithm of the net income divided by total assets. Additionally, the standard deviation for ROA is 0.085 with a minimum value of -0.512 and a maximum value of 0.356 . Similarly, ROE has a mean of 0.068 , with it being calculated as the natural logarithm of the net income divided by shareholder equity. It has a standard deviation of 0.239 , a minimum of -2.769 , and a maximum value of 0.604 . Moreover, IND has a mean value span ranging from $14 \%$ to $87.5 \%$, indicating that the ratio of independent board members varies considerably within transportation firms. The mean value of IND is $51 \%$, which signifies that CMA guidelines for public limited firms listed on the Saudi Stock Exchange are being followed. As pointed out in the literature review above, the guidelines require firms to have a board made up of at least one-third independent members.

Table 2

The summary of the statistics

\begin{tabular}{|c|c|c|c|c|}
\hline Variables & Mean & Standard Deviation & Minimum & Maximum \\
\hline ROA & 0.054 & 0.085 & -0.512 & 0.356 \\
\hline ROE & 0.068 & 0.239 & -2.769 & 0.604 \\
\hline IND & 51.464 & 17.986 & 14.286 & 87.5 \\
\hline BMEET & 4.805 & 1.743 & 2 & 10 \\
\hline BSIZE & 8.076 & 2.018 & 6 & 11 \\
\hline LEV & 0.363 & 0.209 & 0.016 & 0.869 \\
\hline SIZELG & 15.013 & 1.521 & 11.958 & 19.645 \\
\hline
\end{tabular}

Furthermore, MEET has a mean of 4.8, indicating a reasonable frequency of BMEET on an annual basis. It also has a standard deviation of 1.743 with a minimum number of meetings recorded within the sample of 2 meetings, and a maximum number of 10 meetings a year. This indicates that Saudi transportation firms vary in terms of the frequency of meetings on an annual basis. Similarly, the mean of BSIZE sample is 8 , indicating that the mean of board size of Saudi transportation firms conforms to the optimal size proposed by Jensen (1993) who advocates that the best size is between seven and eight. However, the standard deviation value is 2, with the minimum BSIZE being 6 and the maximum being 11. These figures are in line with the requirement of the CG code in Saudi Arabia, which mandates a minimum of 3 board members and a maximum of 11. As for the control variables, the mean of LEV is 0.36 with a standard deviation of 0.2 , with a minimum of 0.016 and a maximum of 0.87 . Finally, SIZELG has a mean of 15 with a standard deviation of 1.5 , with a minimum value of 11.96 and a maximum value of 19.645. Table 3 below shows Pearson's correlation matrix of all variables. The crucial value of the test is to see whether the independent variables show any signs of multicollinearity, meaning that there is a likelihood that there is strong correlation between the independent variables, thereby rendering the statistical analysis invalid when fitting the model and attempting to interpret the results. However, looking at the table we can clearly see that there is no strong correlation between the independent variables. The rule of thumb behind Pearson's correlation test is that the correlation values between any two independent variables should not be, or exceed, 0.8. The data shown in Table 3 provide clear agreement with this rule.

Table 3

The summary of the Pearson's Correlation matrix

\begin{tabular}{|c|c|c|c|c|c|c|c|}
\hline & ROA & ROE & IND & MEET & BSIZE & LEV & SIZELG \\
\hline ROA & 1.000 & & & & & & \\
\hline ROE & 0.812 & 1.000 & & & & & \\
\hline IND & -0.173 & -0.230 & 1.000 & & & & \\
\hline BMEET & -0.070 & -0.150 & 0.262 & 1.000 & & & \\
\hline BSIZE & 0.017 & -0.043 & 0.279 & 0.197 & 1.000 & & \\
\hline LEV & -0.476 & -0.280 & -0.086 & -0.143 & -0.159 & 1.000 & \\
\hline SIZELG & 0.016 & 0.056 & -0.253 & 0.135 & 0.371 & 0.267 & 1.000 \\
\hline
\end{tabular}

Table 4 below reports the pooled OLS regression analysis results. These estimate the relationship between BC and FP for the first dependent variables. The table is divided into three panels, with Panel A presenting the analysis results of the relationship between BMEET frequency and FP based on two performance proxies - ROA and ROE. Similarly, Panel B reports the relationship between IND and performance, while Panel C shows the results in terms of BSIZE and performance. Looking at the table we can note from Panel A that, contrary to expectations in terms of predicted sign, there is a significant negative relationship between BMEET frequency and FP (both proxies). Therefore, the results allow us to accept Hypothesis 1 which lends support to Johl et al. (2015) and Taghizadeh and Saremi (2013). These results signify that frequent board meetings may not always lead to a positive impact on FP. 
Moreover, Panel B reveals the pooled OLS regression analysis results that estimate the relationship between board members' independence and FP. Looking at the table we can see that the analysis reveals that IND is associated with FP for both performance proxies (ROA and ROE) which allows us to accept Hypothesis 2. However, the direction of the relationship is negative, which indicates that the higher the proportion of IND, the lower the performance of the sampled firms. Such findings offer a contradicting perspective to the resource dependence theory proposed by Pfeffer and Salancik (2003). The finding also rejects the view that a high proportion of IND enhances FP as suggested by Sarpong-Danquah et al. (2018).

Table 1

Pooled OLS Results of BC and Performance. Panel A Meetings and Performance (ROA \& ROE) Panel B Independence and Performance (ROA \& ROE). Panel C BSIZE and Performance (ROA \& ROE)

\begin{tabular}{|c|c|c|c|c|c|c|c|}
\hline \multirow{2}{*}{$\begin{array}{l}\text { Panel A } \\
\text { Variables } \\
\end{array}$} & \multicolumn{2}{|c|}{$\begin{array}{c}\text { ROA-Meetings } \\
\end{array}$} & \multicolumn{4}{|c|}{$\begin{array}{l}\text { ROE-Meetings } \\
\end{array}$} & \multirow[b]{2}{*}{ P-value } \\
\hline & Predicted sign & Coefficients & t Stat & P-value & Coefficients & t Stat & \\
\hline Intercept & & 0.020 & 0.388 & 0.699 & -0.063 & -0.408 & 0.684 \\
\hline BMEET & + & -0.009 & -2.870 & 0.005 & -0.031 & -3.425 & 0.001 \\
\hline LEV & - & -0.225 & -8.819 & 0.000 & -0.414 & -5.305 & 0.000 \\
\hline SIZELG & + & 0.010 & 3.000 & 0.003 & 0.029 & 2.684 & 0.008 \\
\hline Adj R Square & & 0.27 & & & 0.13 & & \\
\hline Panel B & \multicolumn{2}{|c|}{\begin{tabular}{|c|} 
ROA-Independence \\
\end{tabular}} & \multicolumn{4}{|c|}{ ROE-Independence } & \\
\hline Variables & Predicted sign & Coefficients & t Stat & P-value & Coefficients & t Stat & P-value \\
\hline Intercept & & 0.088 & 1.532 & 0.127 & 0.172 & 0.98 & 0.328 \\
\hline IND & + & -0.001 & -3.122 & 0.002 & -0.003 & -3.565 & 0.000 \\
\hline LEV & - & -0.213 & -8.520 & 0.000 & -0.369 & -4.828 & 0.000 \\
\hline SIZELG & + & 0.006 & 1.707 & 0.089 & 0.013 & 1.185 & 0.237 \\
\hline Adj R Square & & 0.27 & & & 0.14 & & \\
\hline Panel C & \multicolumn{2}{|c|}{ ROA-BSIZE } & \multicolumn{4}{|c|}{ ROE-BSIZE } & \\
\hline Variables & Predicted sign & Coefficients & t Stat & P-value & Coefficients & t Stat & P-value \\
\hline Intercept & & 0.002 & 0.045 & 0.964 & -0.127 & -0.816 & 0.415 \\
\hline BSIZE & + & -0.007 & -2.312 & 0.022 & -0.022 & -2.497 & 0.013 \\
\hline LEV & - & -0.229 & -8.684 & 0.000 & -0.422 & -5.207 & 0.000 \\
\hline SIZELG & + & 0.013 & 3.259 & 0.001 & 0.035 & 2.949 & 0.004 \\
\hline Adj R Square & & 0.26 & & & 0.11 & & \\
\hline
\end{tabular}

Additionally, panel $\mathrm{C}$ reveals the pooled OLS regression analysis results that estimate the relationship between BOD size and FP. It was expected that the direction of the relationship would be positive, which would indicate that a larger BOD is perceived to lead to enhanced FP. However, looking at the results shown in Panel C, we can see that the relationship between BSIZE and performance is highly significant, hence Hypothesis 3 is accepted. Nevertheless, the sign here is negative, which leads to new insights regarding the direction of the relationship between BSIZE and FP. Such findings provide support for the free rider effect and the view that larger boards hinder effectiveness and the decision-making process (Kao et al., 2018; Jensen, 1993; Lipton and Lorsch, 1992; Dwivedi and Jain, 2005). It furthermore contradicts the opposing viewpoint that larger boards offer robust monitoring and provide opportunities for better FP (Ramdani \& van Witteloostuijn, 2010; Adams \& Ferreira, 2007; Mangena et al., 2012; Choi et al., 2007; Kiel and Nicholson, 2003; Lefort and Urzu a, 2008). Nevertheless, these findings suggest that smaller boards are more effective, conceivably due to the efficiency factor associated with a limited number of board members.

\section{Conclusion}

This paper attempted to examine the association between the characteristics of BOD and FP using two dependent variables to capture the financial performance of the firm. The two dependent variables utilized in this paper are ROA and ROE. Similarly, the BC considered in this paper are BMEET, IND and BSIZE. The analysis cast doubts on the mainstream perspective regarding the optimal characteristics of BOD. For instance, the findings seem to indicate that frequent board meeting may not lead to improved FP. On the contrary, the results provide insights into the distracting effect of too many meetings. Moreover, in contrast to previous studies, the findings suggest that a larger number of independent members does not provide additional efficiency leading to a better performance. As for BSIZE, the findings indicate that larger boards are associated with lower FP. Such findings offer insights into the effect of BSIZE on FP. Recent developments with regard to the CG scene provide CG with a promising role in the materials sector firms listed in the TASI. Such endeavors have attempted to elevate the efficiency of CG practices which may help in retaining market participants' confidence in the importance of the BOD in enhancing the financial performance of firms. This study offers additional insights into a variety of parties regarding suggested best practices with regard to CG. For instance, the findings offer another perspective for policymakers regarding BMEET, independence, and size. Similarly, investors and shareholders may benefit from the findings in terms of the potential attributes of efficient BODs in terms of their meetings' frequency, independence, and size. Nevertheless, this paper has inherent limitations in terms of its sample. Due to the selection of the materials sectors of the TASI, the results cannot be generalized to the overall population of the TASI. Therefore, promising research avenues may evolve around investigating this phenomenon using selected sectors or about the overall population (after excluding financial firms due to their distinctive requirements and business model). Additionally, potential research arenas could 
consider the moderating effect of audit quality such as audit fees and the presence of the Big4 auditing firms. Such research designs might enable researcher to explore the determinants of FP, especially those pertaining to BC.

\section{References}

Adams, R.B., \& Ferreira, D. (2007). A theory of friendly boards. The Journal of Finance, 62(1), 217-250.

Aljifri, K., \& Moustafa, M. (2007). The impact of corporate governance mechanisms on the performance of UAE firms: an empirical analysis. Journal of Economic and Administrative Sciences, 23(2), 71-93.

Al-Matari, E.M., Fadzil, F.H., \& Al-Swidi, A.K. (2014). The moderating effect of board diversity on the relationship between board of directors characteristics and firm performance in Oman: Empirical study. Middle East Journal of Scientific Research, 21(5), 782-791.

Bhagat, S., \& Black, B. (2001). The Non-Correlation between board independence and Long-Term firm performance. Journal of Corporate Law, 27(2), 231-273.

Bhatt, R.R., \& Bhattacharya, S. (2017). Family firms, board structure and firm performance: evidence from top Indian firms. International Journal of Law and Management, 59(5), 699-717.

Cavaco, S., Crifo, P., Rebe rioux, A., \& Roudaut, G. (2017). Independent directors: less informed but better selected than affiliated board members?. Journal of Corporate Finance, 43, 106-121.

Choi, J.J., Park, S.W., \& Yoo, S.S. (2007). The value of outside directors: evidence from corporate governance reform in Korea. Journal of Financial and Quantitative Analysis, 42(4), 941-996.

CMA, (n.d). Capital Markets Authority of Saudi Arabia.

Dahya, J., \& McConnell, J.J. (2007). Board composition, corporate performance, and the Cadbury committee recommendation. Journal of Financial and Quantitative Analysis, 42(3), 535-564.

De Andres, P., Azofra, V., \& Lopez, F. (2005). Corporate boards in OECD countries: size, composition, functioning and effectiveness. Corporate Governance: An International Review, 13(2), 197-210.

Dwivedi, N., \& Jain, A. (2005). Corporate governance and performance of Indian firms: the effect of board size and ownership. Employee Responsibilities and Rights Journal, 17(3), 161-172.

Eluyela, D.F., Akintimehin, O.O., Okere, W., Ozordi, E., Osuma, G.O., Ilogho, S.O., \& Oladipo, O.A.n (2018). Board meeting frequency and firm performance: examining the nexus in Nigerian deposit money banks. Heliyon, 4(10), p.e00850.

Fama, E.F., \& Jensen, M.C (1983). Separation of ownership and control. The journal of law and Economics, 26(2), 301325.

Haniffa, R., \& Hudaib, M. (2006). Corporate governance structure and performance of Malaysian listed companies. Journal of Business Finance \& Accounting, 33(7-8),1034-1062.

Jensen, M.C. (1993). The modern industrial revolution, exit, and the failure of internal control systems. The Journal of Finance, 48(3), 831-880.

Jensen, M.C., \& Meckling, W.H. (1976). Theory of the firm: managerial behavior, agency costs and ownership structure. Journal of Financial Economics, 3(4), 305-360.

Johl, S.K., Kaur, S., \& Cooper, B.J. (2015). Board characteristics and firm performance: Evidence from Malaysian public listed firms. Journal of Economics, Business and Management, 3(2), 239-243.

Kakanda, M., Bello, A., \& Abba, M. (2016). Effect of capital structure on the performance of listed consumer goods companies in Nigeria. Research Journal of Finance and Accounting, 7(8), 211-219.

Kao, M.F., Hodgkinson, L., \& Jaafar, A. (2018). Ownership structure, board of directors and firm performance: evidence from Taiwan. Corporate Governance: The International Journal of Business in Society, 19(1).

Kiel, G.C., \& Nicholson, G.J. (2003). Board composition and corporate performance: how the Australian experience informs contrasting theories of corporate governance. Corporate Governance: An International Review, 11(3), $189-205$.

Lefort, F., \& Urzu' a, F. (2008). Board independence, firm performance and ownership concentration: evidence from Chile. Journal of Business Research, 61(6), 615-622.

Lipton, M., \& Lorsch, J.W. (1992). A modest proposal for improved corporate governance. Business Lawyer, 48(1), $59-77$.

Ministry of Commerce (2016). Companies Law.

Mangena, M., Tauringana, V., \& Chamisa, E. (2012). Corporate boards, ownership structure and firm performance in an environment of severe political and economic crisis. British Journal of Management, 23, S23-S41.

Pfeffer, J., \& Salancik, G.R. (2003). The external control of organizations: A resource dependence perspective. Stanford University Press.

Prevost, A.K., Rao, R.P., \& Hossain, M. (2002). Board composition in New Zealand: an agency perspective. Journal of Business Finance \& Accounting, 29(5/6), 731-760.

Ramdani, D., \& van Witteloostuijn, A. (2010). The impact of board independence and CEO duality on firm performance: a quantile regression analysis for Indonesia, Malaysia, South Korea and Thailand. British Journal of Management, 21(3), 607-627.

Sarpong-Danquah, B., Gyimah, P., Afriyie, R.O., \& Asiamah, A. (2018). Corporate governance and firm performance: An empirical analysis of manufacturing listed firms in Ghana. Accounting and Finance Research, 7(3), 111-118.

Taghizadeh, M., \& Saremi, S. (2013). Board of directors and firms performance: Evidence from Malaysian public listed firm. International Proceedings of Economics Development and Research, 59, 178. 
Weir, C., Laing, D., \& McKnight, P.J. (2002). Internal and external governance mechanisms: their impact on the performance of large UK public companies. Journal of Business Finance \& Accounting, 29(5-6), 579-611.

Zabri, S.M., Ahmad, K., \& Wah, K.K. (2016). Corporate governance practices and firm performance: Evidence from top 100 public listed companies in Malaysia. Procedia Economics and Finance, 35, 287-296.

Zhou, H., Owusu-Ansah, S., \& Maggina, A. (2018). Board of directors, audit committee, and firm performance: evidence from Greece. Journal of International Accounting, Auditing and Taxation, 31, 20-36. 
(C) 2022 by the authors; licensee Growing Science, Canada. This is an open access article distributed under the terms and conditions of the Creative Commons Attribution (CC-BY) license (http://creativecommons.org/licenses/by/4.0/). 